\title{
O Demônio do Ouro, de Camilo Castelo BRANCO: UM OUTRO ROMANCE HISTÓRICO DE (MAIS) UM MESTRE NA (SEMI)PERIFERIA DO CAPITALISMO \\ O Demônio do Ouro (The Gold's Devil), by Camilo Castelo Branco: another historical novel of a(nother) master in the (semi) periphery of Capitalism
}

\author{
Luciene Marie Pavanelo*
}

\begin{abstract}
RESUMO
O objetivo deste artigo é analisar o romance histórico $\mathrm{O} D$ mônio do Ouro, de Camilo Castelo Branco. Se aparentemente a obra reproduz os modelos importados, representados pelo nacionalismo de Walter Scott e pelas aventuras de Alexandre Dumas e Ponson du Terrail, numa leitura mais atenta verificamos que o escritor critica esses mesmos modelos, propondo um outro tipo de romance histórico, no qual a crítica social e o questionamento aos pressupostos estéticos estrangeiros se destacariam, desviando-se das expectativas de leitura do público oitocentista.
\end{abstract}

Palavras-chave: Camilo Castelo Branco; O Demônio do Ouro; romance histórico.

\begin{abstract}
The aim of this article is to analyze the historical novel $O$ Demônio do Ouro, by Camilo Castelo Branco. If the work apparently reproduces the imported models, represented by Walter Scott's nationalism and Alexandre Dumas and Ponson du Terrail's adventures, we verify, upon a closer scrutiny, that the writer
\end{abstract}

* Doutora em Estudos Comparados de Literaturas de Língua Portuguesa pela Universidade de São Paulo (USP) 
criticizes these same models, proposing another kind of historical novel, in which the social criticism and the questioning of the foreign aesthetic assumptions would stand out, deviating from the reading expectations of the $19^{\text {th }}$ century audience.

Keywords: Camilo Castelo Branco; O Demônio do Ouro; historical novel.

\section{O SUBGÊNERO ROMANCE HISTÓRICO}

Tendo sido um dos subgêneros mais apreciados pelo leitor oitocentista, o romance histórico difundiu-se no mundo lusófono através das traduções de escritores como Walter Scott, Alexandre Dumas e Victor Hugo. Segundo Helena Carvalhão Buescu, em Portugal Scott começa a ser traduzido em 1819 e passa a ser muito lido nos anos 1830, tornando-se durante as décadas de 1840 e 1850, "ao lado sobretudo de Hugo e A. Dumas (mas também de Frédéric Soulié), um dos polos referenciais da composição romanesca, sobretudo de matriz histórica" (BUESCU, 1997, p. 357).

Atraído pelo pitoresco da ambientação em tempos remotos, bem como pelas aventuras heroicas de capa e espada presentes principalmente na produção do escritor de Os Três Mosqueteiros, o público consumia avidamente esse tipo de romance, cujo precursor em Portugal, como sabemos, fora Alexandre Herculano. Em Lendas e Narrativas (1851), Herculano defende a descoberta da nação e a valorização de suas raízes, a fim de construir o subgênero histórico em solo português. Como ele afirma, é objetivo do romancista "desentranhar do esquecimento a poesia nacional e popular dos nossos maiores: trabalhamos por ser historiadores da vida íntima de uma grande e nobre, e generosa nação, que houve no mundo, chamada nação portuguesa" (HERCULANO, 1986, p. 191).

Pinheiro Chagas, por sua vez, defende numa passagem de seus Ensaios Críticos (1866) que "a pátria do romance histórico devera ter sido Portugal! [...] Poucas nações têm tido, como a portuguesa, uma existência tão aventurosa! Poucas têm na sua história tantos episódios dramáticos!" (CHAGAS, 1866, p. 51). Após exaltar os feitos de Portugal desde a Idade Média até o princípio do século XIX, que poderiam servir de rica matéria para o gênero, o autor descreve a geração de seus avós como "uma geração de gigantes, tal foi a grandeza épica dos feitos que então se praticaram" (CHAGAS, 1866, p. 52). Segundo ele,

em épocas assim fervem os assuntos do romance histórico. Um povo, cujas paixões estão concitadas em supremo grau, um povo 
heroico, exagerado, brutal na defesa da sua nacionalidade, é digno do estudo do romancista. Em cada peleja obscura, em cada emboscada há um episódio dramático (CHAGAS, 1866, p. 54).

Assim, em sua meta de ensinar o leitor sobre a História de seu país, o romance histórico pretendia assumir "a tarefa de vulgarizar o conhecimento e formar as massas populares: deste modo, o romance vem preencher uma função de utilidade social" (MARQUES, 2010, p. 113). Nas palavras de Arnaldo Gama, em Um Motim Há Cem Anos (1861), "a maneira de ensinar a história àqueles que não se aplicam aos livros, àqueles cuja profissão os arreda de poder fazer estudos sérios e seguidos, é o romanceá-la, dialogando-a, e dando vida à época, dando vida aos personagens, dando vida às localidades [...]" (GAMA, 1861 apud MARQUES, 2010, p. 113).

Como forma de valorizar a nação e promover o seu conhecimento, os romancistas investiam na caracterização espaço-temporal, através da descrição minuciosa da paisagem natural ou dos ambientes internos, bem como dos costumes e tradições da época retratada. De acordo com Maria de Fátima Marinho, a "constituição do ambiente" é um "fenômeno sem o qual é praticamente impossível pensar em romance histórico, tal como o Romantismo o concebia" (MARINHO, 1992, p. 104), sendo então "importante aquilo a que vulgarmente se chama cor local" (MARINHO, 1992, p. 105, grifo da autora). Por outro lado, como György Lukács explica, "Walter Scott nunca subestimou tais elementos pictóricos e descritivos. Utilizou-os até com tanta força que críticos superficiais viram nesse aspecto justamente o essencial de sua arte" (LUKÁCS, 2011, p. 58) - críticos (e autores), é importante que se ressalte, não somente do século XX, mas também do Oitocentos. Pinheiro Chagas, por exemplo, é um dos que viram outras qualidades no escritor de Ivanhoé, a despeito da opinião corrente: para ele, "o gênio admirável de Walter Scott reproduzia com vivíssimo colorido os animados quadros do viver anterior da sua pátria" (CHAGAS, 1866, p. 59); contudo,

o que excitava o interesse, o que promovia o sucesso não era a verdade dos retratos, não era a ressurreição perfeita da época, era a aparição desses vultos extraordinários, para que seriam mesquinhas as telas da atualidade, era a narração dessas poéticas aventuras, a que não podem assistir os membros da geração prosaica, que vive neste século das conveniências (CHAGAS, 1866, p. 60).

Assim sendo, o que Chagas julga ser essencial no romance histórico é o fato de nele podermos encontrar vultos extraordinários, ou seja, personagens que representam valores não mais encontrados na sociedade 
oitocentista. No entanto, como defende Lukács, apesar de na época ter sido interpretado dessa forma, "Scott não foi um romântico, um venerador ou um poeta elegíaco dos tempos passados" (LUKÁCS, 2011, p. 74). Segundo ele, ao contrário, o escritor escocês

[...] procura o "caminho do meio" entre os extremos e esforça-se para demonstrar sua realidade histórica pela figuração ficcional das grandes crises da história inglesa. Essa tendência fundamental de sua figuração se expressa de imediato no modo como ele inventa a trama e escolhe a personagem principal. O "herói" do romance scottiano é sempre um gentleman inglês mediano, mais ou menos medíocre (LUKÁCS, 2011, p. 49).

Scott é

Com isso, na visão de Lukács, o importante para escritores como

[...] desvelar de maneira figurada as imensas possibilidades humanas e heroicas que se encontram latentes no povo e emergem à superfície "de repente", com fúria monstruosa, sempre que uma grande ocasião se apresenta, sempre que há uma comoção profunda na vida social ou mesmo na vida pessoal mais imediata. A grandeza dos períodos de crise da humanidade repousa, em grande medida, no fato de que tais forças ocultas permanecem latentes no povo e só necessitam de uma ocasião que as deflagre para vir à tona. [...] O que queriam mostrar é que as possibilidades desse salto humano, desse heroísmo, estão presentes nas massas populares e muitos membros do povo vivem tranquilamente sua vida, sem nenhum salto, apenas porque não passam por uma experiência que leve a tal concentração de forças. Precisamente por isso é que as revoluções são as grandes épocas da humanidade, porque nelas e por meio delas ocorrem os movimentos de ascensão das capacidades humanas (LUKÁCS, 2011, p. 72).

Sendo assim, de acordo com a leitura de Lukács, em Walter Scott o herói é o homem médio comum, responsável pelas transformações sociais, erigidas em tempos de crise. O teórico critica a forma como a figura do herói foi construída durante o século XIX nos romances históricos românticos, que se distanciam do retrato scottiano: segundo o seu ponto de vista, "as grandes personagens históricas da época são os heróis de seus romances e, em conformidade com o 'trabalho da fantasia popular', eles são representados por uma série de anedotas de caráter pitoresco e acompanhados de reflexões moralistas" (LUKÁCS, 2011, p. 100). Como explica Ana Maria Marques, sobre 
os personagens dos romances históricos portugueses, "quanto aos heróis, não podemos falar de semelhanças com o modelo escocês: trata-se agora de verdadeiros heróis românticos, dominados pelo excesso das paixões que não conseguem controlar e impelidos desesperadamente para um final trágico" (MARQUES, 2010, p. 104). Segundo Helena Buescu, Alexandre Herculano e seus seguidores possuiriam um "intuito ideológico" que faria "convergir no herói a particularização de uma causa coletiva, que aliás não faz elidir o projeto pessoal (e passional) que também o define como herói" (BUESCU, 1997, p. 357). O típico romance histórico romântico centrar-se-ia no período medieval porque é nele que se "encontra a conformação dos grandes valores e dos grandes ideários nacionais, corporalmente assumidos através de várias personagens, de entre as quais avulta o herói” (BUESCU, 1997, p. 357).

Para Pinheiro Chagas, o romance histórico teria sofrido um processo de degeneração durante o século XIX, decaindo até chegar a As Aventuras de Rocambole (1857-1870), de Ponson du Terrail. Segundo o crítico, a partir de Walter Scott, o subgênero teria sido continuado por Alexandre Dumas, que teria tomado "por tema de infinitas variações a índole das diferentes épocas, que ele não estudava mas adivinhava" (CHAGAS, 1866, p. 60), tendo bordado

[...] na tela da história ficções a qual mais engenhosa, embelezadas com quantos lavores e matizes lhe proporcionava a sua opulenta fantasia, e o seu engenho verdadeiramente descomunal. Esta feiticeira degeneração do romance histórico foi acolhida com dobrado entusiasmo do público (CHAGAS, 1866, p. 60).

De acordo com Maria Lúcia Dias Mendes, Dumas "ficava muito distante do nacionalismo que movia o "bardo escocês'" (MENDES, 2002, p. 40). Como ela explica, "na década de 1840 [na França], já não era mais uma questão de afirmação ou legitimação política e artística [...], mas sim de um romantismo mais bem comportado, 'um romantismo de salão elegante'" (MENDES, 2002, p. 41, grifo da autora). As aventuras de capa e espada passaram a agradar mais do que o resgate da História gloriosa da nação: o entretenimento passou, assim, a ser colocado em primeiro lugar. Nas palavras de Chagas,

Depois o romance histórico foi continuando a resvalar pela perigosa ladeira, para onde o impelira Dumas. [...] O que importava a degeneração aos leitores, se as peripécias se iam tornando cada vez mais impossíveis, e por conseguinte mais curiosas? Às fantasiadas mas fantasiosas narrações de Dumas sucediam as lucubrações abstrusas de espíritos enfermos. Hoje a imaginação assusta-se ao 
contemplar o caminho percorrido pelo romance histórico, a imensa distância que separa Ponson du Terrail de Walter Scott (CHAGAS, 1866, p. 61, grifo do autor).

Assim, o romance histórico parece ter passado por várias "fases", que, em Portugal, foram divididas pela crítica numa primeira, de tema medieval, representada principalmente pelas obras de Herculano e Almeida Garrett, e numa segunda, em que se passa a preferir "temas mais atuais e épocas menos recuadas" (MARQUES, 2010, p. 97). Segundo Ana Maria Marques, nessa segunda fase "começa a desvanecer-se o interesse pelo medievalismo [...], e a obra de Rebelo da Silva reflete claramente essa mudança: o século XVIII e as invasões francesas passam, agora, a ser épocas repetidamente convocadas" (MARQUES, 2010, p. 97). Com isso, a partir das características aqui esboçadas - a valorização da nação, o heroísmo do povo português e o relato grandiloquente de sua História -, é possível depreendermos os aspectos mais valorizados e as expectativas de leitura, em Portugal, para o típico romance histórico romântico. Refletiremos, a seguir, como Camilo Castelo Branco tratou dessas questões.

\section{O romance histórico de Camilo Castelo Branco}

Quando partimos para a leitura de $O$ Demônio do Ouro: romance original (1873-1874), de Camilo Castelo Branco, deparamo-nos com um quadro bastante diverso do que o que esboçamos em nossa introdução. A obra é revestida de aspectos que claramente remetem ao subgênero: o enredo se passa, em sua primeira parte ${ }^{1}$, durante o século XVIII - período usualmente retratado pelos romancistas históricos portugueses da "segunda fase", como explicamos anteriormente -; além disso, alguns personagens fictícios da trama interferem num fato real da História - a Inconfidência Mineira -, interagindo com figuras históricas como Tiradentes e os poetas árcades brasileiros. Contudo, numa leitura mais detida, percebemos alguns desvios que merecem ser discutidos.

Nesse romance, Portugal é apenas um de seus espaços, o que nos chama a atenção, tendo-se em vista que o típico romance histórico romântico

1 O Demônio do Ouro é divido em duas partes, a primeira ambientada na segunda metade do século XVIII, e a segunda no início do século XIX, com enredo bastante diverso e com outros personagens - os herdeiros de um dos protagonistas da primeira parte. Como o nosso objetivo aqui é trabalhar com o romance histórico, acreditamos ser mais conveniente analisar somente a primeira parte da obra. Dessa forma, está implícito que, sempre que nos referirmos a esse romance, estaremos nos referindo à sua primeira parte. 
procurava, sobretudo, o resgate e a valorização da História do próprio país. Ao contrário, encontramos nessa obra uma rede de deslocamentos tão rica que chega a surpreender o leitor contemporâneo, habituado à imagem de Camilo como um escritor das "províncias nortenhas no seu tempo", conforme as palavras de António José Saraiva e Óscar Lopes na clássica História da Literatura Portuguesa (SARAIVA; LOPES, 1996, p. 779). Nela, o enredo se passa em Portugal, Londres e Brasil, sendo também citados outros países como Índia, Canadá, Irlanda, Itália, Holanda e Alemanha.

o início da trama é semelhante ao de muitos romances do autor. Trata-se da história de Manuel Vieira, um menino órfão que é adotado por uma família pobre da Póvoa de Lanhoso. Quando cresce, o rapaz sai à procura de trabalho e consegue um emprego de caixeiro numa casa comercial que negociava a importação e exportação de vinho e algodão, pertencente a uma família de ingleses - os irmãos Bearsley -, com sedes no Porto, Londres e Bengala. Com isso, o fato de as ações se passarem em vários lugares mostra que o foco do autor não está na promoção da História de Portugal. Logo no primeiro capítulo, aliás, o paradigma do romance histórico é colocado em xeque pelo narrador numa longa passagem em que descreve - com intuito paródico - os pormenores históricos em torno de monumentos da Póvoa de Lanhoso, questionando ironicamente o seu estatuto de verdade:

Sobranceando a Póvoa, negrejava o castelo de Lanhoso, ereto em rocha, recortado de ameias, lardeado de bastiões, golpeado de seteiras, ali perpetuado, rebatendo as injúrias de nove séculos, imagem, símbolo da raça forte que, ao passar por lá, empedrou um dos seus gigantes, como vigia eterna das gerações que se desforçam a camartelo da sua vergonhosa afeminação [...]. Lá foi que D. Rodrigo Gonçalves Pereira de Berredo, esposo atraiçoado por um frade de Bouro, pegou o fogo pelos quatro ângulos, assando a esposa, o frade, os criados, as bestas, tudo, criminosos e inocentes, desde a adúltera até o frade, o frade talvez inocentíssimo, embora o genealógico D. Pedro, conde de Barcelos, mentiroso como todos os linhagistas, referindo o caso, duvide da inocência do monge (CASTELO BRANCO, 1987, p. 333).

Ao referir-se ao pai adotivo de Manuel Vieira, o narrador afirma que tais "referências históricas decerto não preocupavam o ânimo de João Veríssimo. Os monumentos da velha Galiza, aquelas relíquias dos netos de Pelágio não lhe preponderavam tanto no espírito como os seis anos da criança que não tinha mãe, e não sabia a quem dar nome de pai" (CASTELO BRANCO, 1987, p. 333). Com isso, ao mesmo tempo que critica a inutilidade e a falta de relevância, a seu ver, do resgate da História - e, consequentemente, do 
romance histórico - para o povo, Camilo evidencia que a crítica social está no centro de sua obra.

O patrão de Manuel é retratado pelo narrador como um inglês honrado e bom, que ajuda o rapaz a subir na carreira e enriquecer, dando-lhe salários proporcionais à competência e honestidade do caixeiro. Seu caráter é descrito logo no início, quando o protagonista precisa escolher entre a proposta de emprego do inglês e a de um comerciante português: como ele afirma, "Desconfiei que o português queria enganar o outro, por isso me agraciei menos dele; e também porque o português me falou com modos brutais, e o outro [o inglês] com bondade, tratando-me como se eu estivesse bem vestido" (CASTELO BRANCO, 1987, p. 360). No momento em que o narrador contrapõe o honrado comerciante inglês ao desonesto português, vemos um denegrimento da imagem do povo lusitano, em vez do ufanismo usualmente apregoado pelos romances históricos.

Além disso, o enredo mostra que em Portugal o menino pobre sofrera preconceito ao pedir esmolas nas ruas e, quando jovem, tem dificuldade de arranjar emprego pela falta de recomendações. Quando a mãe adotiva de Manuel sugere enviá-lo para Braga ou para o Porto para procurar trabalho, o seu marido responde: "Quem conheces tu lá, mulher! [...] A quem havemos de o mandar? Tu cuidas que Manuel chega a qualquer dessas cidades, e, sem proteção nem recomendação de ninguém, encontra patrão que o aproveite?" (CASTELO BRANCO, 1987, p. 354). É sua filha quem sugere a solução: "Peço ao padrinho das Agras que me dê uma carta para alguém de Braga ou do Porto" (CASTELO BRANCO, 1987, p. 354). Dessa forma, temos que a única saída para os mais pobres, em Portugal, é depender da proteção dos mais ricos, dos grandes proprietários, numa relação de favor que muito se assemelha aos vínculos de dependência encontrados no Brasil imperial. Nesse sentido, Camilo não mostra um pendor nacionalista, mas antes uma crítica à perversa sociedade portuguesa, movida pelas aparências e por práticas como o apadrinhamento, que tolhem as oportunidades dos menos favorecidos.

Manuel, no entanto, não precisou recorrer a esse estratagema para conseguir o seu emprego de caixeiro, uma vez que encontrou o patrão inglês por acaso, ao intervir numa discussão em que este estava sendo enganado pelo comerciante português. Indo trabalhar na Inglaterra, o rapaz consegue ser respeitado e valorizado pela sua competência, acabando por ganhar muito dinheiro e ser bem-sucedido. Parece-nos que, aqui, Camilo aproveita-se do mito do self-made man, muito difundido nos romances ingleses do século XVIII, como explica Sandra Vasconcelos: "o romance inglês é um forte instrumento na propagação da ideia de que há lugar para todos no mundo capitalista e que a ascensão social é uma possibilidade aberta para quem quer que se esforce por ela" (VASCONCELOS, 2005, p. 208). Sabemos que na 
Inglaterra, como afirma Eric Hobsbawm, "as carreiras do mundo burguês estavam de fato abertas ao talento, mas as famílias com um certo grau de educação, propriedade e ligações sociais, entre outras, certamente começavam com uma enorme vantagem relativa" (HOBSBAWM, 2007, p. 335). Entretanto, se tal fato dificultava a ascensão social dos mais pobres, não era um impeditivo: "Em que medida eram [os trabalhadores] recém-promovidos a partir das classes mais baixas? Não em grande número, embora em teoria nada impedisse a sua ascensão social" (HOBSBAWM, 2007, p. 334). Em Portugal, por outro lado, segundo Camilo, a proteção de um grande proprietário era obrigatória para conseguir um emprego, tanto no próprio país, como no Brasil - cujos comerciantes também exigiam dos portugueses imigrantes cartas de recomendação -, o que explicita as diferenças entre os centros e as periferias, onde os mitos do capitalismo nem de longe se verificam.

Assim, Manuel Vieira muda-se para Londres, onde acontece boa parte da história. Quando acontece um crime - um dos funcionários da casa comercial, Johnson Fowler, falsifica documentos e comete um assassinato com o intuito de roubar os irmãos Bearsley -, há boatos de que o assassino teria fugido para o Canadá, mais um país que entraria na rota de deslocamentos atlânticos traçada por Camilo: "as indagações da polícia descobriram que ele, dias antes, havia tirado passaporte para o Canadá" (CASTELO BRANCO, 1987, p. 390). Fowler, na verdade, acaba fugindo para o Brasil, e a sua fuga, com a apropriação de identidades falsas, mostra a intensa relação entre vários países europeus:

[...] encontrou-se registrado o passaporte de um Gower, padre católico irlandês, que ia à Itália [...]; descobriu-se que ele havia embarcado em navio holandês com destino a Pernambuco, posto que o consignatário da casa nos Países Baixos dissesse que o passageiro lhe apresentara o seu passaporte em que se intitulava George Jonathan Holland, filósofo de profissão, natural de Rosenfeld, no ducado de Wurtemberg, casado com Maria Van Hooft, natural de Middelbourg (CASTELO BRANCO, 1987, p. 400).

Somente neste parágrafo temos citadas a Irlanda, Itália, Holanda e Alemanha - esta através do filósofo, que realmente existiu, Georg Jonathan Holland (1742-1784), que o narrador camiliano não deixa de satirizar: "o infame [Fowler] passara deleitosamente a copiar assinaturas, não poupando a do sábio Jonathan, que, àquela hora, estava talvez lucubrando na sua adiposa obra intitulada Reflexóes Filosóficas sobre o Sistema da Natureza" (CASTELO BRANCO, 1987, p. 400, grifo do autor). Este, aliás, não é o único filósofo setecentista que revive na obra de Camilo: os franceses também 
aparecem, quando o narrador apresenta o pretendente da filha de Bearsley como o "filho natural do conde de Chesterfield, nascido em França de uns famosos amores que o douto lorde, amigo de Voltaire e Montesquieu, lá contraíra em anos juvenis" (CASTELO BRANCO, 1987, p. 379).

Filipe de Chesterfield, um típico aristocrata inglês e "futuro conde" (Cf. CASTELO BRANCO, 1987, p. 379), é prometido a Ana Bearsley, que também era requisitada pelo vilão Johnson Fowler. Antes de roubar a casa comercial, Fowler convence o tio dela, seu patrão, de que o rapaz queria se casar com a moça por interesse, uma vez que estaria imerso em dívidas, apresentando-lhe uma letra falsificada, em nome de Filipe (Cf. CASTELO BRANCO, 1987, p. 379-380). Ao ser confrontado pelo tio de Ana com a letra falsa, o rapaz exaspera-se:

- Eu não escrevi esta assinatura; pela minha honra o juro! E, se não puder provar que a minha assinatura foi falsificada, matar-me-ei! As contorções de assombro e cólera eram mais persuasivas que o protesto do suicídio em um país onde o spleen matava mais gente que o receio da desonra (CASTELO BRANCO, 1987, p. 381, grifo do autor).

Neste trecho, Camilo ridiculariza a "misantropia inglesa, doença deplorável que o suicídio nos dá a perceber como a terribilíssima crise da saciedade dos prazeres" (CASTELO BRANCO, 1987, p. 405), típica dos românticos que viam na morte a única saída, desvelando a convencionalidade do spleen, uma vez que a ameaça de Filipe de se matar não comovera o seu interlocutor. Ressentido por ter sido desacreditado pelos Bearsley, o fidalgo parte numa viagem para o Brasil, a fim de esquecer o amor contrariado. Coincidentemente, numa reviravolta folhetinesca, Filipe acaba desvendando na então colônia portuguesa o paradeiro do criminoso, que havia se hospedado na casa de sua meia-irmã.

A aventura se passa, assim, no Pará, às margens do rio Amazonas, cenário que serve de ensejo para que o autor se utilize da imagem estereotipada do Brasil como um país de "robustos índios" (Cf. CASTELO BRANCO, 1987 , p. 409) e florestas virgens - o que agradaria ao seu leitor habituado às narrativas de viagem em terras americanas, escritas por viajantes europeus e muito lidas na época. Além disso, tal imagem também está presente em Gonçalves Dias e José de Alencar, autores já conhecidos no Portugal da década de 1870 , e com os quais Camilo concorria no mercado editorial brasileiro. A paisagem amazônica é retratada pelo narrador camiliano seguindo esses modelos difundidos: 
As margens daqueles rios, artérias pujantes em que arfam as ondas do Amazonas, são ensombradas de árvores giganteias, que fazem tristeza e pavor. [...] E aquele que ali chegou, ido das cidades [...], entrou-se de amargura imensa, e, em meio daquelas vidas colossais, da ave enorme e da árvore que topeta as nuvens com as suas franças, cuida que à volta de si tudo é o infinito vácuo da morte. [...] Ainda, se nos ouvidos da alma lhe rumorejam os mil hinos daqueles silêncios - se por de sobre as copas das florestas lhe vai o espírito desferindo voo em demanda de Deus -, a sua alegria pode ser grande como a do eremita de Ístria [...] (CASTELO BRANCO, 1987, p. 410).

No entanto, baseados no que comumente encontramos na produção camiliana, é possível aqui duvidarmos da sinceridade do narrador. Toda essa prolixa e desnecessária descrição, que não se relaciona com a ação, pode ser justamente uma paródia a esse tipo de narrativa. Isso fica mais evidente quando, páginas adiante, o narrador descreve ironicamente a cena em que Johnson Fowler é encontrado pela polícia, convocada por Filipe:

[...] tomando três soldados [...], desceu à margem do rio, onde Johnson, com inglesa excentricidade, se comprazia de acalentar os sonos ao rouquejante piar das arapongas e guirapongas, dos galeirões, e guarases e japis, e outras aves de nomes igualmente poéticos (CASTELO BRANCO, 1987, p. 415).

A sucessão de termos indígenas da fauna brasileira é aqui claramente inserida de maneira artificial, sem relacionar-se com a ação, evidenciando o intuito de Camilo de parodiar a temática indianista utilizada pelos escritores brasileiros. Nessa abordagem, Fowler é supostamente morto por um dos índios que acompanhavam os policiais (Cf. CASTELO BRANCO, 1987, p. 416), e seu corpo é jogado no rio. O vilão, no entanto, fingira-se de morto, acabando por escapar e indo para o Maranhão, acompanhado da amante brasileira. Em seguida, Camilo dedica um capítulo inteiro para tratar da biografia da amante de Fowler e sua irmã, mulheres de vida dissoluta, com o intuito de parodiar os relatos históricos:

Declinarei de mim a imputação de aleivosia assacada à memória das Senhoras Catânias, trasladando das "Memórias" de D. Fr. João de S. José Queirós algumas linhas biográficas daquelas damas. "A 2 de Janeiro (vem historiando o bispo em linguagem que tresanda a folhetim, pág. 175) descemos pelo mesmo Garapé (freguesia de S. Miguel do Guamá) [...]. É caso que poderá servir de instrução 
ao leitor (de instrução! credo!). Na cidade de Belém ficaram órfãs de pai duas moças. Chamemos Laurentina uma, e Nise a outra. (Honrada pseudonimonia!)". (CASTELO BRANCO, 1987, p. 441, grifo do autor).

Ao inserir seus comentários jocosos, entre parênteses, na suposta transcrição das "Memórias" de um certo Fr. João de S. José Queirós, o narrador camiliano ridiculariza o intuito didático dos relatos históricos - afinal, a vida de tais mulheres não teria nada a ensinar aos leitores. Além disso, há também a interpolação de notas de rodapé, comentando os erros gramaticais do tal Frei, contribuindo para o rebaixamento desse tipo de narrativa: "Não se siga, nesta passagem, a gramática do sábio monge de S. Bento" (CASTELO BRANCO, 1987, p. 441).

Voltando à diegese, o narrador afirma que no Maranhão Fowler adota a identidade de "um estadista que estuda as confederações, repúblicas e impérios americanos" (CASTELO BRANCO, 1987, p. 448), que "dizia conhecer de $t u$ Washington, Boston e outros corifeus da independência [dos Estados Unidos]" (CASTELO BRANCO, 1987, p. 449, grifo do autor). Tal identidade lhe serve para fazer amizade, durante a viagem, com ninguém menos que "um brasileiro de Minas, chamado Joaquim José da Silva Xavier - mais notório pela alcunha de 'Tiradentes'” (CASTELO BRANCO, 1987, p. 448), que lhe confidencia "planos políticos do maior melindre, [...] instando-o a residir temporariamente em Minas Gerais” (CASTELO BRANCO, 1987, p. 449). O personagem camiliano é, assim, colocado ao lado de figuras históricas da Inconfidência Mineira:

Apresentado como homem de Estado da Grã-Bretanha, insinuou-se na estima do celebrado republicano José Alves Maciel de S. João d'El-Rei, dos três poetas Tomás António Gonzaga, Inácio José de Alvarenga Peixoto e Cláudio Manuel da Costa (CASTELO BRANCO, 1987, p. 449).

Sendo “depositário dos segredos da conjuração" (Cf. CASTELO BRANCO, 1987, p. 449), Fowler acaba sendo o responsável direto pela condenação de Tiradentes e seus companheiros, e não Silvério dos Reis, como a História registrou. Isso porque, segundo o narrador, Silvério dos Reis teria somente delatado ao governador a amizade de Fowler com os conjurados e contado que o inglês era "casado com uma sedutora paraense, que alguém reputava amante de Silva Xavier" (CASTELO BRANCO, 1987, p. 450). Ao ter sido interrogado pelo governador - que lhe revela a traição de sua mulher com Tiradentes -, o vilão teria denunciado 
[...] que o brado da revolta devia estalar em Vila Rica, e ele visconde de Barbacena estava votado à morte [...]. Depois nomeou os conjurados [...]. E [...] obrigou-se a espiar o restante processo da revolta, se ao governador conviesse o segredo das revelações feitas (CASTELO BRANCO, 1987, p. 451).

Ao misturar a História e a ficção, Camilo desmerece a traição de Silvério dos Reis, colocando como motivo principal para o fracasso da Inconfidência Mineira um fato prosaico: Fowler teria delatado Tiradentes pelos ciúmes de marido traído. Aliás, retratar Tiradentes como um homem mulherengo também é uma forma que o autor encontra de rebaixar uma personalidade histórica tida como herói no Brasil. As figuras históricas portuguesas, bem como a própria História de Portugal, por sua vez, também não são poupadas da crítica irônica tecida pelo narrador camiliano, que lamenta a violência da política de expansão territorial empregada pelo seu país:

Dizem que a árvore da independência do Brasil hauriu seiva daquele sangue [de Tiradentes]. Certamente, Portugal, ali e em toda a terra e mar onde arvorou a bandeira de Cristo, espontada em lança de bárbaros, foi inconsciente instrumento da civilização dos seus escravos. A rainha que assinou a condenação da lenta morte de Gonzaga, de Alvarenga e Cláudio Manuel da Costa é uma que os livros históricos das escolas denominam a piedosa (CASTELO BRANCO, 1987, p. 454, grifo do autor).

Além disso, é interessante notarmos que o Brasil costuma ser apontado na ficção portuguesa oitocentista - e, principalmente, na produção de Camilo - como um espaço econômico, de enriquecimento. No caso de $O$ Demônio do Ouro, trata-se do espaço em que ocorrem as peripécias mais emocionantes, a aventura - um espaço em que se encontram plasmados os lugares-comuns do romance histórico romântico, sobretudo a tradição dumasiana das aventuras de capa e espada, continuada por autores como Ponson du Terrail. A presença do Brasil como um espaço da aventura agradaria, dessa forma, ao leitor brasileiro, importante consumidor da obra de Camilo, e ao público de aquém e além-mar, que apreciava esse tipo de narrativa.

Por fim, fica-nos a pergunta: qual seria o herói deste romance? o personagem que mais aparece na narrativa camiliana é Johnson Fowler, um ladrão sem nenhum caráter, lembrando-nos Rocambole, de Ponson du Terrail. De acordo com Marlyse Meyer,

Pode-se então dizer que o termo rocambolesco não é somente um estereótipo definindo uma aventura descabelada, mas designa pre- 
cisamente aquele conjunto de ações, conspirações, planejamentos por uma cabeça muito fria, de inteligência ímpar, para a urdidura da trama que permite, utilizando todos os talentos, todos os vícios, subornando, ameaçando, lançando mãos do crime e da sedução, alcançar a qualquer preço, sem o menor escrúpulo, desconhecendo até a menção da moral, a única meta que interessa: o dinheiro (MEYER, 1996, p. 120, grifo da autora).

É interessante notarmos que uma grande parte de $O$ Demônio do Ouro poderia se chamar As Aventuras de Johnson Fowler, em referência à obra de Ponson du Terrail, uma vez que os episódios têm muito de rocambolesco. Para agradar ao leitor que apreciava as peripécias "cada vez mais impossíveis" de Rocambole, nas palavras de Pinheiro Chagas (Cf. CHAGAS, 1866, p. 61), Camilo introduziu em seu romance um personagem criminoso, que viaja por vários países, metendo-se em episódios históricos como a Inconfidência Mineira. No entanto, trata-se de um personagem inglês, estrangeiro - o que nos faz pensar que talvez Camilo tivesse consciência quanto à sua estratégia de importação dos moldes folhetinescos.

Filipe de Chesterfield, um nobre de origem francesa que vive na Inglaterra, seria o personagem que mais se aproximaria da figura do herói romântico, pois captura o vilão Fowler em meio a um cenário exótico e pitoresco - a selva amazônica - tudo pela honra e pelo amor à bela donzela Ana Bearsley. No entanto, como vimos anteriormente, a descrição desse cenário é parodiada das narrativas de viagem e da temática indianista, a partir do contraste entre um tom grandiloquente e um tom cômico, apontando o que esse tipo de descrição teria de ridículo. Esse herói, por outro lado, pouco aparece na história, além de não ser português e, portanto, não representar os valores da nação lusitana. Parece-nos, assim, que Camilo se utiliza desse personagem - como Fowler, também importado - para inserir a aventura heroica no romance, um elemento que muito atraía o leitor oitocentista, sedento por façanhas à la Alexandre Dumas.

Manuel Vieira, apesar de perder a posição central no enredo a partir da metade da narrativa - ainda que a diegese continue estruturada em sua trajetória -, é mostrado no início de O Demônio do Ouro como o seu protagonista e, nas palavras do narrador, "é o herói do romance" (CASTELO BRANCO, 1987, p. 398). Porém, o personagem nada teria de semelhante com os gloriosos heróis do modelo de romance histórico em voga, pois leva uma vida extremamente prosaica e não se envolve em nenhuma aventura - o que talvez justifique o fato de ter sido colocado em segundo plano na ação, em prol de personagens mais interessantes e romanescos, como Fowler e Filipe. Como o narrador camiliano jocosamente afirma, "o montanhês de Lanhoso como que ainda conservava o selvagismo nativo, e certo não podia ser 
personagem de romance que levasse o fito posto em espantar pessoas tão pouco espantadiças como hoje em dia são os consumidores destes livros" (CASTELO BRANCO, 1987, p. 398). Aparentemente, Manuel Vieira não é digno de representar o ideário heroico da nação portuguesa - a não ser que o romance estivesse querendo mostrar que Portugal justamente careceria desse tipo de heroísmo. A partir desse questionamento da figura do herói, o autor apresenta uma visão mais lúcida da História, que teria sido construída pelo homem comum, que luta pela sobrevivência e - na Idade Contemporânea - pela ascensão financeira.

Em O Demônio do Ouro, Manuel Vieira também é um homem "mediano" e "medíocre", assim como o herói scottiano (Cf. LUKÁCS, 2011, p. 49); todavia, Portugal não está passando por nenhuma grande crise histórica, e nenhum conflito social é resolvido no romance. Quando lemos Camilo, a impressão que temos é de que nada muda - Portugal está "engessado", e o autor não parece acreditar numa transformação efetiva, de ordem coletiva. $\mathrm{Na}$ esfera individual, por sua vez, o homem comum é obrigado a se deslocar para outros países à procura da tão desejada mobilidade social.

o romance mostra que a fortuna, contudo, não é garantia de felicidade: Manuel Vieira acaba a história desgostoso e esmorecido. Rico, casa-se com a namorada de infância, não tem filhos e passa o resto de seus dias melancólico, lamentando as crueldades cometidas pela hipócrita sociedade oitocentista. Quando conhece a sua irmã, como ele, filha de uma mulher amante de um padre, percebe as dificuldades pelas quais muitos outros conterrâneos passam:

[...] [a moça] parecia ainda temer-se do cárcere da Tamanca, narrando os desprezos que sua mãe sofrera, as injúrias que lhe atiravam ao coração despedaçado. Depois, falecida a mártir, e acabados os recursos da comiseração dos parentes, acorrentaram a órfã ao posto da indigência para ainda a insultarem como filha de tal mãe e sacrílega filha dum padre que havia sido a vergonha do clero. Manuel Vieira [...] sofria, escutando-a; e já lhe pedia que se esforçasse por esquecer-se, a fim de não perder a fé na criação da espécie humana delineada na mente do Criador à semelhança de sua própria imagem (CASTELO BRANCO, 1987, p. 467).

Enriquecido, Manuel pode ter resolvido os problemas financeiros de sua família; entretanto, não resolveu os problemas de toda uma sociedade. Além disso, o dinheiro também não é visto como uma solução definitiva: na segunda parte do romance, os herdeiros de Vieira (irmãos, sobrinhos, parentes e amigos) engalfinham-se pela herança deixada por ele. Nas palavras proféticas de seu pai moribundo, que encerram a primeira parte da 
obra, "[...] o anjo do infortúnio faz muito menos vítimas que o demônio do ouro" (CASTELO BRANCO, 1987, p. 468). Com isso, percebemos que Camilo nunca aponta uma saída - talvez por não acreditar verdadeiramente numa melhora no estado de coisas. O título de $O$ Demônio do Ouro refere-se, assim, à "maldição" da riqueza, e o que as pessoas são capazes de fazer por dinheiro, abandonando todos os princípios éticos e morais. Além disso, o título também remete ao ciclo do ouro em Minas Gerais, período em que acontece a Inconfidência Mineira, pano de fundo que contribui no diálogo da narrativa camiliana com o subgênero histórico. Assim sendo, segundo Ana Maria Marques,

[...] longe do objetivo didático e de glorificação do passado nacional que é apanágio dos românticos Herculano ou Arnaldo Gama, o romance histórico de Camilo serve-se da História com uma finalidade estética e claramente comercial (MARQUES, 2010, p. 243).

Para a pesquisadora, o autor transformaria "o passado numa fonte de boas histórias e num pretexto para algumas horas de 'leitura amena'" (MARQUES, 2010, p. 243). A nosso ver, no entanto, não se trata de somente levar o entretenimento para o público: ao mesmo tempo que oferece aquilo que o seu leitor queria consumir - um enredo de aventuras, repleto de referências a figuras históricas -, em o Demônio do Ouro Camilo vai além do esperado num romance histórico romântico e promove a crítica à sociedade oitocentista - principalmente a portuguesa -, em vez de optar pelo elogio ufanista. Contudo, apesar de sua tentativa de conscientização do público para as injustiças sociais, o autor não parece acreditar no poder transformador do povo - uma vez que a raiz dos problemas da nação se encontraria em seus próprios habitantes, com sua hipocrisia, ganância, desonestidade e tradição de dependência dos grandes proprietários -, o que distanciaria o seu romance do modelo scottiano.

Enfim, como procuramos mostrar em nossa análise, Camilo despreza o caráter educativo do romance histórico típico, questionando o tipo de conhecimento que ele leva ao leitor. O estudo da História, da maneira como é usualmente feito no século XIX pelos biógrafos, historiadores e romancistas, é por ele visto como acessório e inútil - assim como a descrição do pitoresco e da cor local - para a resolução dos problemas reais da sociedade. Como lembra Eduardo Lourenço, "inúmeras novelas de Camilo têm um enquadramento 'histórico', reportam-se ao passado mas não há nelas nenhuma paixão do passado como tal, nem da História com maiúscula [...]" (LOURENÇO, 2006, p. 62 , grifo do autor). Dessa forma, $O$ Demônio do Ouro também propõe a crítica aos moldes romanescos estrangeiros - representados pela figura 
heroica e convencional de Filipe de Chesterfield e pelo ladrão rocambolesco Johnson Fowler -, que não corresponderiam à realidade portuguesa, mais próxima de um personagem prosaico como Manuel Vieira.

Com isso, em vez de simplesmente reproduzir em solo nacional os lugares-comuns do subgênero histórico em voga no século XIX, provenientes da França e da Inglaterra, em $O$ Demônio do Ouro o escritor português opta por produzir um outro tipo de romance histórico, com características próprias. Através de uma aparente adesão ao modelo folhetinesco com o intuito de atender às demandas do público leitor, o autor acaba por propor ao mesmo tempo uma subversão desse mesmo modelo, desviando-se das expectativas de leitura. Como procuramos mostrar em nossa análise, Camilo Castelo Branco desvela a inadequação, em Portugal, da aplicação dos pressupostos estéticos importados dos centros do capitalismo europeu, merecendo, sem grandes exageros, compartilhar com Machado de Assis o título, proposto por Roberto Schwarz, de mestre na periferia - ou semiperiferia, se utilizarmos o termo cunhado por Boaventura de Sousa Santos - do capitalismo².

\section{REFERÊNCIAS}

BUESCU, Helena Carvalhão. Narrativa histórica. In: Literário Português. Lisboa: Caminho, 1997. p. 356-362.

(Coord.). Dicionário do Romantismo

CASTELO BRANCO, Camilo. O Demônio do Ouro: romance original. In: Porto: Lello \& Irmão, 1987. v. 7, p. 325-619. . Obras Completas.

CHAGAS, M. Pinheiro. Ensaios Críticos. Porto: Casa de Viúva Moré, 1866.

HERCULANO, Alexandre. Lendas e narrativas. In: As Melhores Obras de Alexandre Herculano. [S.l.]: Círculo de Leitores, 1986. Tomo 2, v. 7, p. 191.

HOBSBAWM, Eric J. A Era do Capital: 1848-1875. 12. ed. Tradução: Luciano Costa Neto. São Paulo: Paz e Terra, 2007.

LOURENÇO, Eduardo. O tempo de Camilo ou a ficção no país das lágrimas. In: . As Saias de Elvira e Outros Ensaios. Lisboa: Gradiva, 2006. p. 59-72.

LUKÁCS, György. O Romance Histórico. Tradução: Rubens Enderle. São Paulo: Boitempo, 2011.

MARINHO, Maria de Fátima. O romance histórico de Alexandre Herculano. Línguas e Literaturas, Porto, v. 9, p. 97-117, 1992. Disponível em: <http://ler.letras.up.pt/uploads/ficheiros/2643. pdf>. Acesso em: 10/8/2012.

MARQUES, Ana Maria dos Santos. O Anacronismo no Romance Histórico Português Oitocentista. Dissertação (Doutorado em Literaturas e Culturas Românicas) - Faculdade de Letras, Universidade do Porto, Porto, 2010. Disponível em: <http://repositorio-aberto.up.pt/bitstream/10216/39321/2/tesedoutanamarques000112487.pdf > . Acesso em: 10/8/2012.

2 Agradeço à Fundação de Amparo à Pesquisa do Estado de São Paulo pelo apoio financeiro a esta pesquisa. 
MENDES, Maria Lúcia Dias. Amor e Encenação em La Reine Margot, de Alexandre Dumas. Dissertação (Mestrado em Língua e Literatura Francesa) - Faculdade de Filosofia, Letras e Ciências Humanas, Universidade de São Paulo, São Paulo, 2002.

MEYER, Marlyse. Folhetim: uma história. São Paulo: Companhia das Letras, 1996.

SANTOS, Boaventura de Sousa. Pela Mão de Alice: o social e o político na pós-modernidade. 7 . ed. Porto: Edições Afrontamento, 1994.

SARAIVA, António José; LOPES, Óscar. Camilo Castelo Branco. In: Portuguesa. 17. ed. Porto: Porto Editora, 1996. p. 777-795.

História da Literatura

SCHWARZ, Roberto. Um Mestre na Periferia do Capitalismo: Machado de Assis. 4. ed. São Paulo: Duas Cidades: Editora 34, 2000.

VASCONCELOS, Sandra Guardini Teixeira. Caminhos do romance inglês no Brasil do século XIX. In: ABREU, Márcia; SCHAPOCHNIK, Nelson (Orgs.). Cultura Letrada no Brasil: objetos e práticas. Campinas: Mercado de Letras, 2005. p. 201-228.

Submetido em: 28/03/2013

Aceito em: 16/07/2013 